\title{
Chelation and Stabilization Properties of Citrulline and Uracil with Hg(II) as a Heavy Metal Ion in Solution
}

\author{
MONIKA SINGH $^{1}$, VIJAY SHANKAR ${ }^{2}$, \\ DHARMVEER SINGH $^{1}$ and VIJAY KRISHNA ${ }^{1 *}$ \\ ${ }^{1}$ Department of Chemistry, University of Allahabad, Allahabad-211002, (U.P.), India \\ ${ }^{2}$ Department of Chemistry, B.S. N.V. P.G. College, Lucknow -226001 (UP), India \\ vkrishnaalld@rediffmail.com
}

Received 2 March 2017 / Accepted 5 April 2017

\begin{abstract}
Potentiometric studies of mercury(II) complex with amino acids and nucleobases in ternary system has been carried out in aqueous solution. The equilibrium studies of quaternary complexes $\mathrm{Hg}$ (II)- $L$-Citrulline(A)- Uracil (B) with different transition metal ions $\mathrm{M}=\mathrm{Cu}$ (II), $\mathrm{Zn}$ (II) $\mathrm{Co}$ (II) and $\mathrm{Ni}$ (II) has been studied at temperature $37 \pm 1{ }^{\circ} \mathrm{C}$ and ionic strength $\mathrm{I}=0.1 \mathrm{M} \mathrm{NaNO}$. The obtained ternary and quaternary system potentiometric data were analysed using computer program SCOGS (Stability Constant of Generalized Species). The analysed binary, ternary and quaternary species by SCOGS are shown in the species distribution curves. The protonation constant of ligands $\mathrm{A}$ and $\mathrm{B}$ and stability constants of its complexes such as MA, MB, MAB and Hg-M-AB type found to be following Irving William order. The $\mathrm{Hg}$ (II)- $\mathrm{Cu}$ (II), $\mathrm{Hg}$ (II)-Co(II), $\mathrm{Hg}$ (II)- $\mathrm{Zn}$ (II) and $\mathrm{Hg}$ (II)$\mathrm{Ni}$ (II) quaternary species occurred complexing within the $\mathrm{pH}$ range of 3-9 and the maximum percent concentrations found to be $80,76,78$ and 70 , respectively at $\mathrm{pH}$ range 5- 6 .
\end{abstract}

Keywords: Citrulline, Formation constant, Speciation curves, SCOGS, Chelation

\section{Introduction}

Coordination complexes mostly have chelation phenomenon as an important aspect in chemistry. Particularly, it enables the metals to be transported to or form vulnerable target sites and to winder their carcinogenic potential. Studies on mixed-ligand and mulitmetal multiligand complexes i.e. ternary and quaternary forms have got intensive interest during the last few years. The field of analytical ${ }^{1-3}$ chemistry, where the use of mixed ligand complexes has facilitates the development of new methods with increased selectivity and sensitivity. The interaction of metal ions with nucleobases like Uracil etc. provides both coordination chemists ${ }^{4}$ and biochemists with grist for their experimental mills for a long time. Also, numerous applications of such complexes with specific ligands has made researchers to attract in the field of environmental, biological ${ }^{5-7}$, medicinal industrial and electrochemical chemistry ${ }^{8-12}$. Macro ligands like DTPA, an octadentate ligand possess eight donor sites viz. three nitrogen $(\mathrm{N})$ and five oxygen $(\mathrm{O})$ for chelation. Numerous such ligands 
are found to be of biological importance and showed potential towards sensor and electrochemical applications ${ }^{13}$. In living systems, complexation of transition metal ions like $\mathrm{Cu}(\mathrm{II}), \mathrm{Co}(\mathrm{II}), \mathrm{Cd}(\mathrm{II})$ and $\mathrm{Zn}(\mathrm{II})$ etc. with amino acid and peptides has been studied as a model for showing equilibrium in such enzymatic process ${ }^{14} . L$ - Citrulline (Figure 1), abbreviated as Cit, $\mathrm{H}_{2} \mathrm{NC}(\mathrm{O}) \mathrm{NH}\left(\mathrm{CH}_{2}\right) \mathrm{CH}\left(\mathrm{NH}_{2}\right) \mathrm{COOH}$, a non-essential $\alpha$-amino acid, first isolated in 1930 from watermelon Citrullus lanatus. Citrulline is made from ornithine and carbamoyl phosphate in one of the central reactions in the urea cycle. It takes part in the synthesis of urea by donating one of its nitrogen. It is also produced from arginine as a byproduct of the reaction catalyzed by NOS family. It is found in high concentration in the liver, promotes energy and assists with the immune system.<smiles>NC(=O)NCCC[C@H](N)C(=O)O</smiles>

Figure 1. Structure of $L$ - Citrulline

Recent antibody research has found that the presence of citrulline antibodies in the blood has been associated with a greater tendency toward more destructive forms of rheumatoid arthritis. Although the origin of this immune response is not known, detection of antibodies reactive with citrulline anti-citrullinated protein antibodies containing proteins or peptides is now becoming an important help in the diagnosis of rheumatoid arthritis.

Keeping an eye on the above factors, the present work is concerned with the study of stability constant, formation equilibria, speciation curves and coordination of some ternary and quaternary ${ }^{15}$ chelates involving $L$-Citrulline and Uracil ${ }^{16,17}$ with $\mathrm{Hg}(\mathrm{II})$ as a heavy metal ions has been performed under biologically relevant conditions.

\section{Experimental}

All reagents used were of A.R. grade (sigma). Solutions were prepared in double distilled $\mathrm{CO}_{2}$ free water. Metal nitrate solutions were standardized by EDTA complexometric titration $^{18,19}$. Carbonate free $\mathrm{NaOH}$ solution was used as titrant ${ }^{20}$ Binary M:A/M:B $(1: 1)$, ternary $\mathrm{M}: \mathrm{A}: \mathrm{B}(1: 1: 1)$ and quaternary $(1: 1: 1: 1) \mathrm{M}_{1} \mathrm{M}_{2} \mathrm{AB}$ metal-ligand mixtures of following composition were prepared for titration, keeping total volume $50 \mathrm{~mL}$ in each case. Strength of metal and ligand kept at $0.001 \mathrm{M}$ and $\mathrm{I}=0.1 \mathrm{M} \mathrm{NaNO}_{3}$.

Solution A: $5 \mathrm{~mL} \mathrm{NaNO}_{3}(1.0 \mathrm{M})+5 \mathrm{~mL} \mathrm{HNO}_{3}(0.02 \mathrm{M})+$ water

Solution B: $5 \mathrm{~mL} \mathrm{NaNO}_{3}(1.0 \mathrm{M})+5 \mathrm{~mL} \mathrm{HNO}_{3}(0.02 \mathrm{M})+5 \mathrm{~mL} \mathrm{~A}(0.01 \mathrm{M})+$ water

Solution C: $5 \mathrm{~mL} \mathrm{NaNO}_{3}(1.0 \mathrm{M})+5 \mathrm{~mL} \mathrm{HNO}_{3}(0.02 \mathrm{M})+5 \mathrm{~mL} \mathrm{~A}(0.01 \mathrm{M})+5 \mathrm{~mL} \mathrm{M}(\mathrm{II})$ $(0.01 \mathrm{M})+$ water

Solution D: $5 \mathrm{~mL} \mathrm{NaNO}(1.0 \mathrm{M})+5 \mathrm{~mL} \mathrm{HNO}_{3}(0.02 \mathrm{M})+5 \mathrm{~mL} \mathrm{~A}(0.01 \mathrm{M})+5 \mathrm{~mL}$ $\mathrm{M}_{1}$ (II) $(0.01 \mathrm{M})+5 \mathrm{~mL} \mathrm{~B}(0.01 \mathrm{M})+$ water

Solution E: $5 \mathrm{~mL} \mathrm{NaNO}(1.0 \mathrm{M})+5 \mathrm{~mL} \mathrm{HNO}_{3}(0.02 \mathrm{M})+5 \mathrm{~mL} \mathrm{~A}(0.01 \mathrm{M})+5 \mathrm{~mL} \mathrm{M}$ (II) $(0.01 \mathrm{M})+5 \mathrm{~mL} \mathrm{~B}(0.01 \mathrm{M})+5 \mathrm{~mL} \mathrm{M}_{2}$ (II) $(0.01 \mathrm{M})+$ water

Where $\mathrm{M}_{1}$ (II) is $\mathrm{Hg}$ (II) and $\mathrm{M}_{2}$ (II) are $\mathrm{Cu}(\mathrm{II}), \mathrm{Zn}$ (II) $\mathrm{Co}$ (II) and $\mathrm{Ni}$ (II)

$\mathrm{A}=$ Citrulline and $\mathrm{B}=$ Uracil. Metal-ligand stability constants (Table 1 ) have been evaluated by SCOGS computer program ${ }^{20}$ values of constants were supplied to the computer as input data to obtain distribution curves of the complexes occurring at different $\mathrm{pH}$. Ionic product of water $(\mathrm{kw})$ and activity coefficient of hydrogen ion under the experimental conditions were obtained from literature ${ }^{21}$. The $\mathrm{pH}$ values were plotted against the volume of $\mathrm{NaOH}$ and the titration curves were obtained. The titrations were discontinued on the appearance of turbidity. 


\section{Results and Discussion}

Citrulline is a diacid, so it is important to consider micro-acidities taking into account the various deportation steps. The micro-acidity constants are presented in Figure 2 which also summarizes the distribution of the different species in water for the complete $\mathrm{pH}$ range figure clearly shows that, under physiological conditions, citrulline is present almost entirely as a zwitter ion. At alkaline $\mathrm{pH}$, both the carboxylic and amine groups can act as lewis donar, which means they can complex metallic cations. The lateral chain is much less complexing, since non-binding electrons of the nitrogen atoms are conjugated with double bond. Various complexes have been reported in aqueous solution ${ }^{22}$.
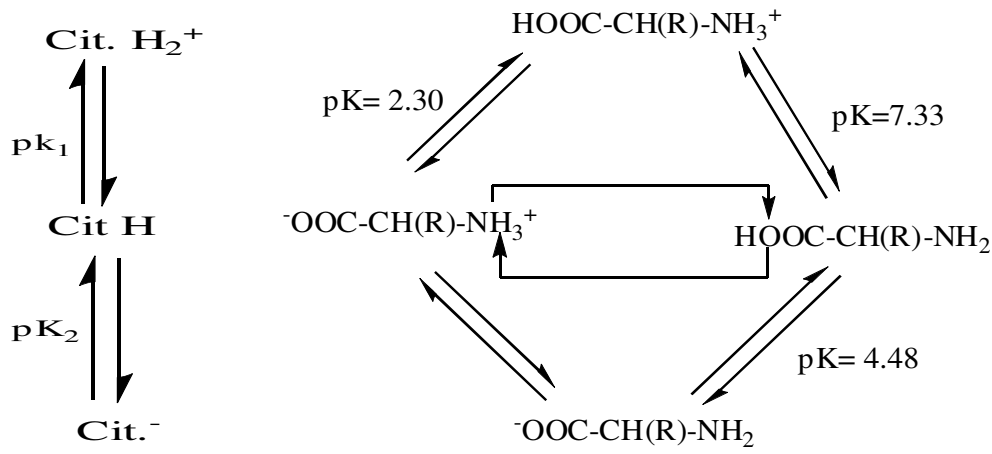

Figure 2. Showing micro-acidities of $L$-Cit in deprotonation steps

Complex formation has been assumed to take place according to following equilibrium:

$$
\begin{gathered}
\mathrm{pM}_{1}+\mathrm{qM}_{2}+\mathrm{rA}+\mathrm{sB}+\mathrm{t}(\mathrm{OH}) \leftrightarrow\left(\mathrm{M}_{1}\right) \mathrm{p}\left(\mathrm{M}_{2}\right) \mathrm{q}(\mathrm{A}) \mathrm{r}(\mathrm{B}) \mathrm{s}(\mathrm{OH}) \mathrm{t} \\
\beta \mathrm{pqrst}=\left[\left(\mathrm{M}_{1}\right) \mathrm{p}\left(\mathrm{M}_{2}\right) \mathrm{q}(\mathrm{A}) \mathrm{r}(\mathrm{B}) \mathrm{s}(\mathrm{OH}) \mathrm{t}\right] /\left[\mathrm{M}_{1}\right] \mathrm{p}\left[\mathrm{M}_{2}\right] \mathrm{q}[\mathrm{A}] \mathrm{r}[\mathrm{B}] \mathrm{s}[\mathrm{OH}] \mathrm{t}
\end{gathered}
$$

Where, $\beta$ pqrst is the overall stability constant, $\mathrm{p}, \mathrm{q}, \mathrm{r}, \mathrm{s}$ are stiochiometeric numbers either 0 or positive integers and $t$ is a negative integer for a protonated species, positive for a hydroxo or a deprotonated species and zero for a neutral species.

Proceeding to find the new formed complexes when a system contains two metals and the above two ligands. $\mathrm{Hg}$ (II)-Cu(II) quaternary system was the most stable with the stability constant and maximum percent of 80 present in the lower $\mathrm{pH}$ region 5. Also, the formation of this species occurred with the commencement of the titration in much higher amount while it was not so in case of other quaternary complexes involving $\mathrm{Hg}$ (II). The $\mathrm{Hg}$ (II)$\mathrm{Co}(\mathrm{II}), \mathrm{Hg}(\mathrm{II})-\mathrm{Zn}(\mathrm{II})$ and $\mathrm{Hg}(\mathrm{II})-\mathrm{Ni}$ (II) quaternary species occurred complexing within the $\mathrm{pH}$ range of 3-9 and the percent concentration of these found to be 76,78 and 70 respectively around $\mathrm{pH}$ 6. SCOGS values showing the stability log values were found to be in accordance of the species concentration.

Complex formation of $\mathrm{Hg}(\mathrm{II})-\mathrm{Cu}(\mathrm{II})$ in the Figure $3 \mathrm{a}$, showed involvement of metal and Protonated ligand species $\mathrm{H}_{3} \mathrm{~A} \mathrm{H}_{2} \mathrm{~A}, \mathrm{HA}$ and $\mathrm{HB}$ as a very low amount of them can be seen by the curves $1,2,3,4$ showing been used in complexation indicating the metal ligand complex formation. At high $\mathrm{pH}$, the binary complex species of $\mathrm{Co}(\mathrm{II}), \mathrm{Ni}$ (II) and $\mathrm{Zn}$ (II) with citrulline and Uracil exist in appreciable amount, but the free metal ion formation pattern gradually decline. The hydroxo species formation like $\mathrm{M}(\mathrm{OH})^{+}$and $\mathrm{M}(\mathrm{OH})_{2}$ maintain at high $\mathrm{pH}$. Speciation curves reveals low concentration of binary species still present with the quaternary mixed metal mixed ligand complex but the later one present in much greater amount. 
Table 1. Stability constant and other related constants of binary, ternary and quaternary complexes of Citrulline (A) and Uracil (B) with different metal ions in aqueous solution at $37 \pm 1{ }^{\circ} \mathrm{C}, \mathrm{I}=0.1 \mathrm{M} \mathrm{NaNO}_{3}$

\begin{tabular}{|c|c|c|c|c|c|}
\hline \multicolumn{6}{|c|}{ (A) Proton -ligand formation constant (Log $\beta$ pqrst) } \\
\hline Ligand & \multicolumn{5}{|c|}{$(\log \beta)$} \\
\hline $\mathrm{H}_{3} \mathrm{~A}$ & \multicolumn{5}{|c|}{15.26} \\
\hline $\mathrm{H}_{2} \mathrm{~A}$ & \multicolumn{5}{|c|}{13.33} \\
\hline $\mathrm{HA}$ & \multicolumn{5}{|c|}{09.63} \\
\hline $\mathrm{HB}$ & \multicolumn{5}{|c|}{08.28} \\
\hline \multicolumn{6}{|c|}{ (B) Hydrolytic constants (Log $\left.\beta_{\text {pqrst }}\right)$} \\
\hline Complexes & $\mathrm{Hg}(\mathrm{II})$ & $\mathrm{Co}(\mathrm{II})$ & $\mathrm{Ni}(\mathrm{II})$ & $\mathrm{Cu}(\mathrm{II})$ & $\mathrm{Zn}(\mathrm{II})$ \\
\hline $\mathrm{M}(\mathrm{OH})^{+}$ & -3.84 & -8.23 & -8.10 & -8.10 & -7.89 \\
\hline $\mathrm{M}(\mathrm{OH})^{2+}$ & -6.38 & -17.83 & -16.87 & -13.10 & -14.92 \\
\hline \multicolumn{6}{|c|}{ (C)Metal -Ligand constant $\left(\log \beta_{\text {pqrst }}\right)$ : Binary system } \\
\hline Complexes & $\mathrm{Hg}(\mathrm{II})$ & $\mathrm{Co}(\mathrm{II})$ & $\mathrm{Ni}(\mathrm{II})$ & $\mathrm{Cu}(\mathrm{II})$ & $\mathrm{Zn}(\mathrm{II})$ \\
\hline MA & 6.02 & 5.95 & 7.16 & 8.57 & 5.84 \\
\hline MB & 13.32 & 5.30 & 5.26 & 6.93 & 5.41 \\
\hline \multicolumn{6}{|c|}{ (D) Metal-Ligand constants $\left(\log \beta_{\text {parst }}\right)$ : Ternary system } \\
\hline Complexes & $\mathrm{Hg}(\mathrm{II})$ & $\mathrm{Co}(\mathrm{II})$ & $\mathrm{Ni}(\mathrm{II})$ & $\mathrm{Cu}(\mathrm{II})$ & $\mathrm{Zn}(\mathrm{II})$ \\
\hline $\mathrm{M}(\mathrm{II})-\mathrm{A}-\mathrm{B}$ & 18.8 & 9.08 & 9.95 & 12.32 & 10.00 \\
\hline \multicolumn{6}{|c|}{ Metal-Ligand constants $\left(\log \beta_{\text {parst }}\right)$ : Quaternary system } \\
\hline Complexes & $\mathrm{Co}(\mathrm{II})$ & $\mathrm{Ni}(\mathrm{II})$ & $\mathrm{Ni}(\mathrm{II})$ & $\mathrm{Cu}(\mathrm{II})$ & $\mathrm{Zn}(\mathrm{II})$ \\
\hline $\mathrm{Hg}(\mathrm{II})-\mathrm{M}_{2}(\mathrm{II})-\mathrm{A}-\mathrm{B}$ & 22.70 & 22.76 & 22.76 & 24.82 & 22.89 \\
\hline
\end{tabular}

On the basis of above description of the speciation curves (Figure 3a-d) obtained through SCOGS, following equilibria have been proposed. The formation of binary species may be attributed to the following equations (1-3) and ternary (4-5).

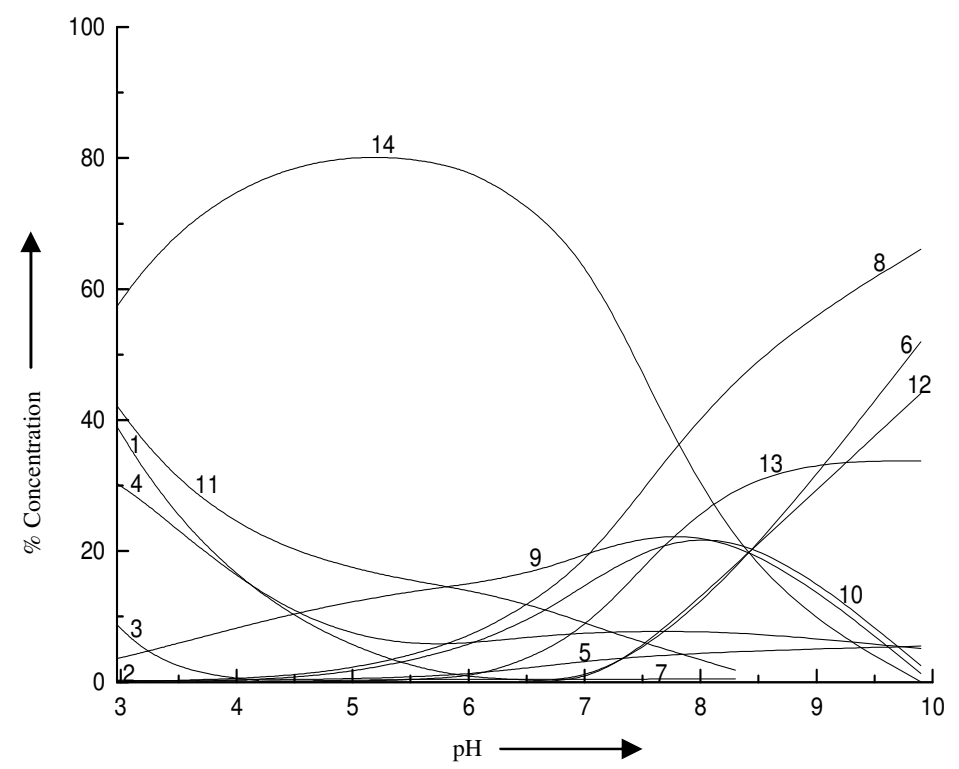

Figure 3a. Distribution curves of 1:1:1:1 Hg(II) - Cu(II)-Citrulline(A) -Uracil(B) system:

$\mathrm{Hg}$ (II) (2) $\mathrm{Cu}$ (II) (3) $\mathrm{AH}_{2}$ (4) $\mathrm{AH}$ (5) $\mathrm{BH}(6) \mathrm{Hg}(\mathrm{OH})_{2}(7) \mathrm{Hg}(\mathrm{OH})^{+}$(8) $\mathrm{Cu}(\mathrm{OH})_{2}$ (9) $\mathrm{Cu}$ (II)- $\mathrm{A}$ (10) $\mathrm{Hg}$ (II)-B (11) Cu(II)-B (12) Hg(II)-A-B (13) Cu(II)-A -B (14) Hg(II)- Cu(II)-A-B 


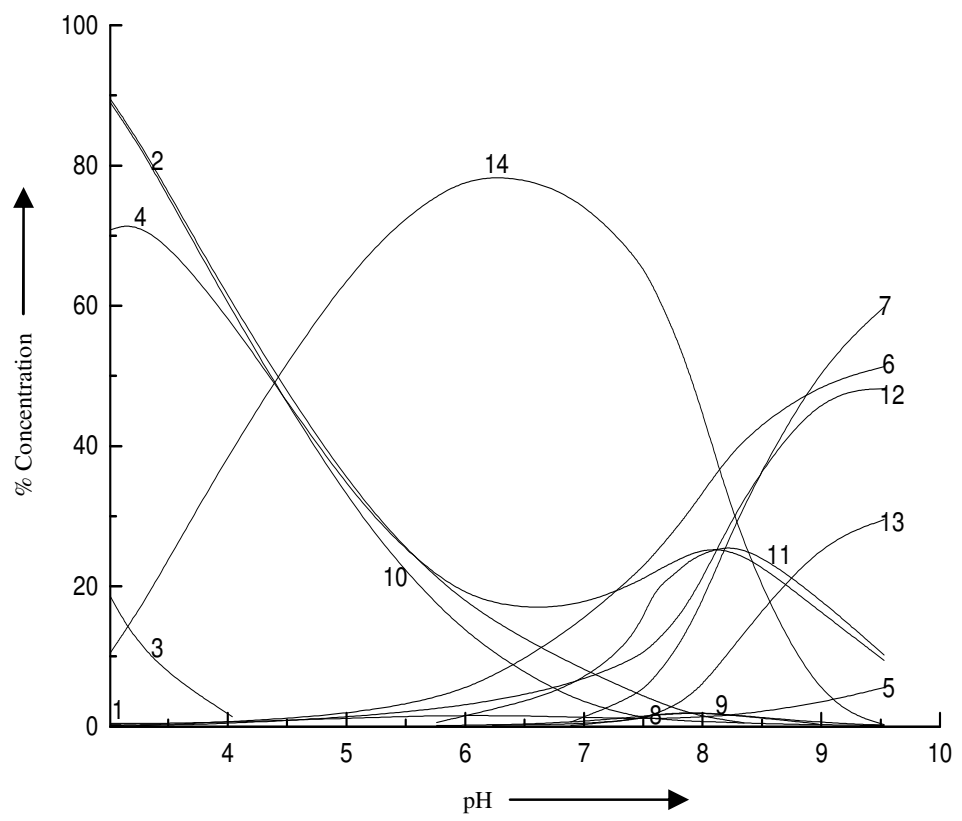

Figure 3b. Distribution curves of 1:1:1:1 $\mathrm{Hg}(\mathrm{II})$ - $\mathrm{Zn}(\mathrm{II})-\mathrm{Citrulline}(\mathrm{A})$-Uracil(B) system: (1) $\mathrm{Hg}(\mathrm{II})(2) \mathrm{Zn}(\mathrm{II})(3) \mathrm{AH}_{2}$ (4) $\mathrm{AH}(5) \mathrm{BH}(6) \mathrm{Hg}(\mathrm{OH})_{2}$ (7) $\mathrm{Zn}(\mathrm{OH})_{2}(8) \mathrm{Zn}(\mathrm{OH})^{+}$(9) $\mathrm{Zn}(\mathrm{II})-$ A (10) Hg(II)- B (11) Zn(II)-B (12) Hg(II)-AB (13) Zn(II)A- B (14) Hg(II)-Zn(II)A- B

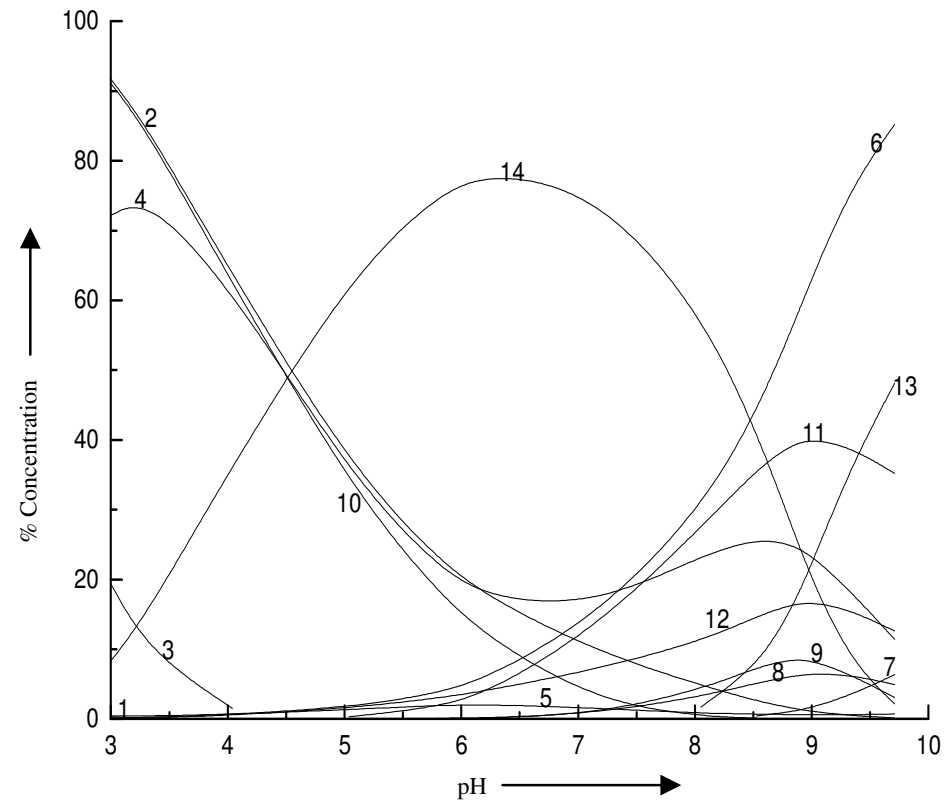

Figure 3c. Distribution curves of 1:1:1:1 Hg(II) -Co(II)-Citrulline(A) -Uracil(B) system: (1) $\mathrm{Hg}$ (II) (2) $\mathrm{Co}$ (II) (3) $\mathrm{AH}_{2}$ (4) $\mathrm{AH}(5) \mathrm{BH}(6) \mathrm{Hg}(\mathrm{OH})_{2}$ (7) $\mathrm{Co}(\mathrm{OH})_{2}(8) \mathrm{Co}(\mathrm{OH})^{+}$(9) $\mathrm{Co}(\mathrm{II})-\mathrm{A}$ (10) $\mathrm{Hg}$ (II)- (B) (11) $\mathrm{Co}(\mathrm{II})-\mathrm{B}$ (12) $\mathrm{Hg}$ (II)-AB (13) $\mathrm{Co}$ (II)-A- B (14) $\mathrm{Hg}$ (II)$\mathrm{Co}(\mathrm{II})-\mathrm{AB}$ 


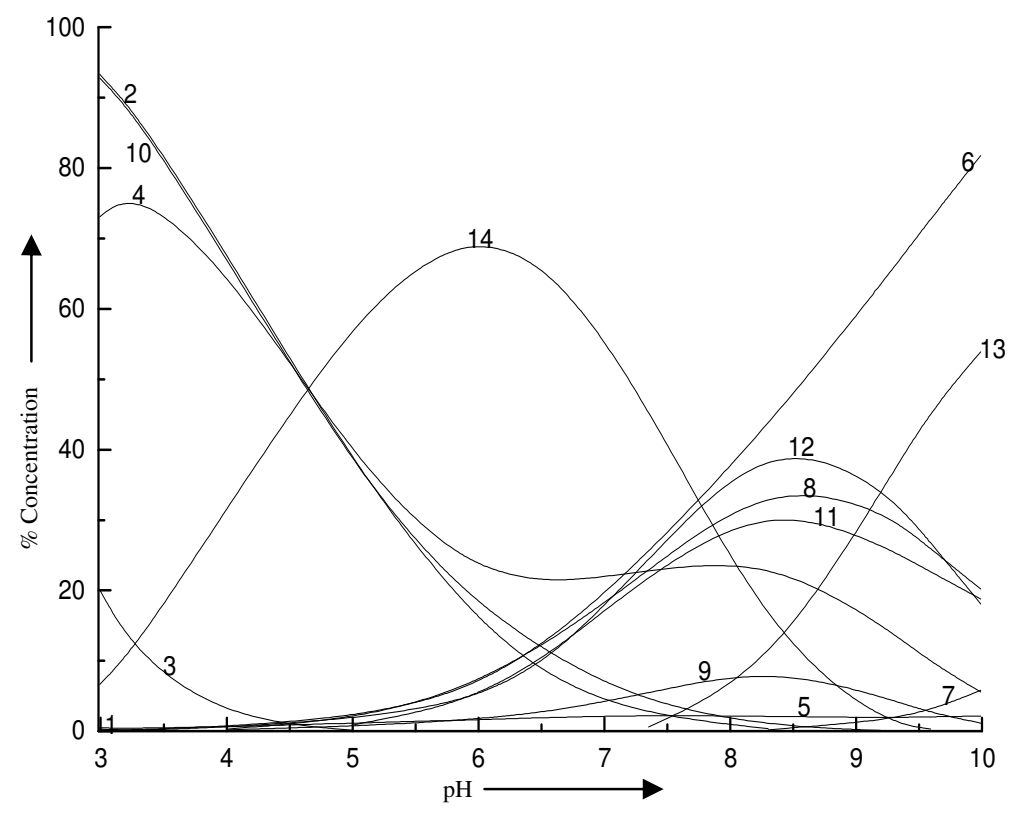

Figure 3d. Distribution curves of 1:1:1:1 Hg(II) -Ni(II)-Citrulline(A) -Uracil(B) system: (1) $\mathrm{Hg}(\mathrm{II})(2) \mathrm{Ni}(\mathrm{II})(3) \mathrm{AH}_{2}$ (4) $\mathrm{AH}(5) \mathrm{BH}(6) \mathrm{Hg}(\mathrm{OH})_{2}$ (7) $\mathrm{Ni}(\mathrm{OH})_{2}(8) \mathrm{Ni}(\mathrm{OH})^{+}$(9) $\mathrm{Ni}(\mathrm{II})-\mathrm{A}$ (10) $\mathrm{Hg}$ (II)- (B) (11) Ni(II)-B (12) $\mathrm{Hg}$ (II)-AB (13) Ni(II)-AB (14) $\mathrm{Hg}$ (II)- Ni(II)-AB

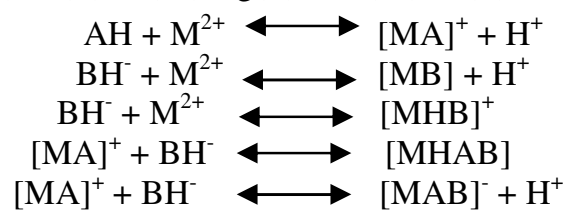

The simultaneous formation of quaternary complex may be expressed as per the equilibria:

$$
\mathrm{HA}+\mathrm{M}_{1}^{2+}+\mathrm{BH}^{-}+\mathrm{M}_{2}^{2+} \longleftrightarrow\left[\mathrm{A}-\mathrm{M}_{1}-\mathrm{B}-\mathrm{M}_{2}\right]^{+}+2 \mathrm{H}^{+}
$$

The buffer regions corresponding to metal-ligand complex formation equilibria have been found to be overlapping with the hydrolytic equlibria of $\mathrm{M}(\mathrm{II})$ (aq.) metal ions. The general hydrolytic equilibria are:

\section{Conclusion}

$$
\begin{aligned}
\mathrm{M}^{2+}+\mathrm{H}_{2} \mathrm{O} & \longmapsto \mathrm{M}(\mathrm{OH})^{+}+\mathrm{H}^{+} \\
\mathrm{M}^{2+}+2 \mathrm{H}_{2} \mathrm{O} & \longrightarrow \mathrm{M}(\mathrm{OH})_{2}+2 \mathrm{H}^{+}
\end{aligned}
$$

Here, all the system under studied, clearly showed the complexation occurred through simultaneous process in all the $\mathrm{M}_{1}$ (II)- $\mathrm{M}_{2}$ (II)-Citrulline-Uracil (1:1:1:1) quaternary systems covering the entire $\mathrm{pH}$ region. In term of complex species, the order was quaternary $>$ ternary>binary, which can be explained based on the increased number of fused rings and the extra stabilization caused by ligand-ligand interactions. Also, the formation of quaternary complexes occur at higher concentration compare to ternary as well as binary complexes at high $\mathrm{pH}$ in each of the system under study and the general formation equilibria is given for each. Relative stability of quaternary complexes in the nature of metal ion is found to follow the trend $\mathrm{Cu}>\mathrm{Zn}>\mathrm{Ni}>\mathrm{Co}$. This is in conformity with the Irving-Williams order, 
also confirmed by the percent species formation in the above diagrams. With this it can be said that quaternary complexes are more helpful in remediation and detoxification of heavy metal ions in vivo compared to the ternary ones because of their extra stability.

\section{Acknowlegdement}

We gratefully acknowledge Rajiv Gandhi Fellowship by University Grant Commission for financial support as Junior Research Fellowship as well as Senior Research Fellowship. Also, very thankful to, The Head, Department of Chemistry, University of Allahabad, for providing us an opportunity to use lab facility.

\section{References}

1. Lipschutz M E, Wolf S F, Hanchar J M and Culp F B, Analy Chem., 1999, 71(12), 1R-20R; DOI:10.1021/a1990003n

2. Sigel A and Sigel H, Metal ions in biological system, Marcel Dekker, New York, 1971-2001, 1-38.

3. Yang X J and Pin C, Analyst, 2000, 3, 453-457; DOI:10.1039/A908278F

4. Martin R B and Sigel H, Metal Ions in Biological Systems. Marcel Dekker, New York, 1979, 9, 1.

5. Eichhorn G L, Inorganic Biochemistry, Elsevier, Amsterdam, 1973, 1, 121.

6. Jack Schubert, Environmental Health Perspectives, 1981, 40, 227-232; DOI: $10.2307 / 3429235$

7. Pratt J M, Inorganic Chemistry of Vitamin B12. London, UK: Academic Press, 1972.

8. Rulisek L and Havlas Z, J Am Chem Soc., 2000, 122, 10428-10439; DOI:10.1021/ja001265g

9. Zubarev R A, Kelleher N L an McLafferty F W, J Am Chem Soc., 1998, 120(13), 3265-3266; DOI:10.1021/ja973478k

10. Syka J E P, Coon J J, Schroeder M J, Shabanowitz J and Hunt D F, Proc Natl Acad Sci., 2004, 101(26), 9528-9533; DOI:10.1073/pnas.0402700101

11. Paavassiliou A G, J Biochem., 1995, 305(2), 345-357; DOI:10.1042/bj3050345

12. Altun Y and Koseoglu F, J Solution Chem., 2005, 34(2), 213-231; DOI:10.1007/s10953-005-2763-7

13. Electrochemical Applications to Biology, Nanotechnology and Environmental Engineering and Materials, Issue 1 Manuel Eduardo Palomar Pardavé, The Electrochemical Society, 2009 - Science-557.

14. De A K, Environmental Chemistry, New ACE International Publisher, $3^{\text {rd }}$ Ed., 1994, 81-83.

15. Bartaria Divya, Shukla V P and Krishna V, J Indian Chem Soc., 2009, 86, 9-13

16. Curis E, Nicolis I, Manard C, Osowska S, Zerrowk N, Benazeth S and Cynober L, Amino Acids, 2005, 29(3), 177-205; DOI:10.1007/s00726-005-0235-4

17. Sarkar A R and Ghosh P, Inorganica Chimica Acta, 1983, 78, L39-L41; DOI:10.1016/S0020-1693(00)86471-3

18. Kolthoyy I M, Sandell B B, Meehan E J and Bruckenstein A, Quantitative Chemical analysis, McMillan, London, 1967(h.4).

19. Schwarzenbach G and Biedermann W, Helv Chim Acta, 1948, 31(2), 331-340; DOI:10.1002/hlca.19480310204

20. Shankar V, Mishra G K and Krishna V, J Indian Chem Soc., 2006, 83(1), 23-5.

21. Sayce I G, Talanta, 1968, 15(12), 1397-1411; DOI:10.1016/0039-9140(68)80200-0

22. Perrin D D, Stability Constants of Metal Ion Complexes, Pergamon, New York, 1979. 